\title{
Beyond a Hagiographic Cliché. On the Supernatural Sustenance of Saint Catherine of Siena
}

\author{
Cătălina-Tatiana Covaciu \\ "Babeş Bolyai" University, Romania \\ catalina_covaciu@yahoo.com
}

\section{Abstract}

From an early age, Saint Catherine of Siena (1347-1380) is told to have drastically reduced her food intake - among other ascetical practices to the point where she only took bitter herbs, cold water, and the host. Eventually, in the wake of the mystic merger with Christ, Catherine became able to live in a completely spiritual manner, without any corporeal nourishment. In fact, scholars emphasize that food deprivation constitutes a recurrent topic in medieval hagiographic accounts, meeting the expectations of the time concerning (especially female) criteria of sainthood. And yet, the saint herself recalls her inedia, so that a more nuanced interpretation of the data is required. Under these circumstances, this chapter proposes a particular focus on sanctity in a theological - namely Christological - perspective, as the saints, who successfully emulate the virtues of the Saviour, are accordingly elevated above earthbound limitations; thus, Catherine's provided original work is properly cited and that this is not done for commercial purposes. Users may not remix, transform, or build upon the material and may not distribute the modified material (http://creativecommons.org/licenses/by-nc/4.0/) 
marvellous condition will be regarded in the light of the genuine belief in the body's transformative potential. Moreover, her painful endeavour to eat according to nature provides the saint with an opportunity to partake in Christ's redemptive suffering.

Keywords: fasting; Christification; living according to the spirit; redemptive suffering; hagiographic topos; Saint Catherine of Siena. 


\title{
Beyond a Hagiographic Cliché. On the Supernatural Sustenance of Saint Catherine of Siena
}

\author{
Cătălina-Tatiana Covaciu \\ "Babeş Bolyai" University, Romania
}

"[Saint Catherine of Siena's] vital functions became so modified, that food was no longer necessary to her, and aliments caused her serious suffering."'1

\section{Introduction}

In the history of medieval Christianity, sainthood appears as a multifaceted phenomenon. From a spiritual, reflexive point of view, it represents the quest for the divine, through a range of behavioural choices intended to lead to a new state of mind, entirely submitted to God's will and permeated by His grace. Furthermore, during the pursuit for godlikeness, the saint - as a living proof of this process adheres to a tradition which puts them in the wake of certain recognized predecessors of whom Jesus Christ is undoubtedly the paragon. However, in a theological and religious perspective, sainthood testifies to the revelation of God's love and to the fact that mankind was meant to be transformed by it. In fact - as Sofia Boesch Gajano asserts - sainthood has two hypostases, as it can be either experienced or venerated, yet they are both historically-conditioned and constitute the result of a deliberate operation of construction. ${ }^{2}$ While the saints

\footnotetext{
${ }^{1}$ Raymond of Capua, The Life of Saint Catherine of Siena (Dublin: James Duffy and Co., s.a.), 98 .

2 S. Boesch Gajano, "Sfințenia”[Sainthood], in Dicționar tematic al Evului Mediu occidental [Thematic Dictionary of Western Middle Ages], ed. Jacques Le Goff, Jean-Claude Schmitt (Iaşi: Polirom, 2002), 734-744, especially 734, 738, 742. In a pioneering study regarding canonized sanctity - addressed in a sociological perspective -, Pierre Delooz
} 
relate to previous models, performing imitatio Christi or imitatio sanctorum, hagiographic works such as vitae or canonization processes knowingly integrate them within a pattern that mirrors the expectations of the day regarding the ideal of Christian perfection. ${ }^{3}$ Of all of these instances, asceticism - and fasting in particular - becomes a recurrence, especially when it comes to women's religious experience, in its lived dimension, but also in hagiographies.

This chapter will consider the case of the fourteenth-century Italian Saint Catherine of Siena (1347-1380), a Dominican tertiary, known for her intense mysticism and fruitful political militancy. She has also developed a firmly body-centred spirituality, characterized - among other features - by a rigorous asceticism, including an extreme fasting practice that ultimately became an inability to nourish according to nature. ${ }^{4}$ Saint Catherine's increasing fasting and eventual foodless

differentiates between the saint as a living person and "le saint construit." Simultaneously, he claims that every venerated saint is, to a certain extent, a "constructed saint," since their image is shaped according to collective mental representations, beyond their historical existence and actual personality. Therefore, sainthood is eventually proclaimed by the community ("saint par les autres") and legally validated by the Church, through the canonization processes. See: S. Delooz, "Pour une étude sociologique de la sainteté canonisée dans l'Eglise catholique", Archives de sociologie des religions, 13 (Jan.- Jun., 1962): 17-43, especially 23, 43.

3 Caroline Walker Bynum, Holy Feast and Holy Fast. The Religious Significance of Food to Medieval Women (Berkeley, Los Angeles: University of California Press, 1987), 82-84. In a foregoing study I have asserted that, retrospectivelty, saints imitate previous models and, prospectively, they become models to be imitated, thus explaining the typologies and the striking similarities between holy people. See: Cătălina-Tatiana Covaciu, "Între memorie şi venerare. Imaginea sfintei Clara de Assisi în procesul de canonizare" [Between Memory and Veneration. The Image of Saint Clare of Assisi in the Canonization Process], Buletinul Cercurilor Ştiintifice Studențeşti Arbeologie - Istorie Muzeologie [Bulletin of Student's Scientific Circles Archeology - History - Museology] 22 (2016): 83-115, especially 91.

${ }^{4}$ I have addressed the topic of Catherine's body-centered religious experience in the paper "What Else Do We Have but a Body? Reflections on an Apparent Paradox", Studia Universitatis Babes-Bolyai, Historia 60/1 (June 2015): 133-154, while her foodrelating practices were the focus of my bachelor thesis, Hrănirea mistică intre patologic și devoțional. Studiu de caz: Sfânta Ecaterina de Siena. Post și subzistenţă spiriutală [Mystical Feeding between Pathology and Devotion. Case Study: Saint Catherine of Siena. Fasting and Spiritual Subsistence], Department of Medieval History, Early Modern History and Art History, unpublished BA thesis ("Babeş-Bolyai" University, ClujNapoca, 2015). Furthermore, Saint Catherine's case is by no means unique. R. Lester, "Embodied Voices: Women's Food Asceticism and Negotiation of Identity", Ethos 23/2 (1995): 187-222, especially 204. In fact, late medieval religious women related to 
subsistence appears in almost all the accounts on her life: her two main vitae, written by Raymond of Capua, respectively Thomas Caffarini, the testimonies in her canonization process and also the canonization bull; 5 moreover, most authors of these texts claim to be direct witnesses of this phenomenon, although - as we will further see - they acknowledge different degrees of intensity with respect to food deprivation. Furthermore, Catherine herself deals with this topic in her writings, a highly unusual stance compared to her general impersonal teachings. ${ }^{6}$ Under these circumstances, a question arises: is radical fasting just a landmark in the process of constructing the image of a saint or is it something more about the survival without corporeal food than a hagiographic cliché?

Before elaborating a response, we will highlight the distinctive traits of our approach, as this subject has largely been addressed and from a variety of standpoints. We will not consider Saint Catherine's food deprivation as a medical condition, ${ }^{7}$ nor her food-related conduct as

the Dominican spirituality were particularly prone to rigorous asceticism, including extreme fasting. P. Ochsenbein, "Mistica della sofferenza nei conventi femminili domenicani del secolo XIV secondo l'esempio di Elsbeth di Oye", in Movimento religioso e mistica femminile nel Medioevo, ed. Peter Dinzelbacher, Dieter Bauer (Roma: Edizioni Paoline, 1993), 398-419.

${ }^{5}$ I have consulted the following editions (in the order mentioned above): The Life (see footnote 1); Tommaso Nacci Caffarini, Vita di S. Caterina da Siena scritta da un divoto della medesima con il supplemento alla vulgata legenda di detta santa, ed. Ambrogio Ansano Tantucci (Siena: Stamperia di Luiggi e Benedetto Bindi, 1765); Il Processo Castellano. Santa Caterina da Siena nelle testimonianze al Processo di canonizzazione di Venez̧ia, ed. Tito S. Centi and Angelo Belloni (Firenze: Edizioni Nerbini, 2009); Bull of Pius II, Appendix at The Life, 390-405.

6 We will stress that there is a definite asymmetry between Catherine's historical personality and the hagiographic portrait framed by her biographers. Her saintliness was rather unusual as it involved ambiguous phenomena - self-starvation being one of them - or the unexpected attitude of political activism. Therefore, the advocates of her sainthood had to employ imaginative strategies: Raymond accentuated the ecstatic dimension of her experience, while Caffarini tried to insert her peculiarities - such as the stigmatization - into tradition. See Heather Webb, "Catherine of Siena's Heart", Speculum 80/3 (Jul. 2005): 802-817, especially 802; Elena Lemeneva, "The Borders and Borderlines of Sainthood: on the Stigmata of St. Catherine of Siena", in Annual of Medieval Studies at Central European University Budapest 6 (2000): 193-202.

7 Within the general concern towards the growing incidence of eating disorders in Western society, in the 1970's and the 1980's, psychoanalysis draws attention to the similarities between anorexia nervosa and ascetical practices coming from various spiritual traditions. One can recall, for instance, Jeffrey Moussaieff Masson's study on 
solely an identity or social statement; ${ }^{8}$ her arduous fasting that will culminate in a supernatural sustenance will be rather deemed an

Hinduism, "The Psychology of the Ascetic" Journal of Asian Studies, 35/4 (August 1976): 611-625. More specifically, related to our topic is the article of the psychiatrist David Rampling, "Ascetic Ideals and Anorexia Nervosa” Journal of Psychiatric Research 19 (1985): 89-94, in which he particularly refers to Saint Catherine of Siena. In his view, her asceticism "included all the behaviors and resulted in the bodily changes which we would identify as characteristic of severe anorexia; moreover, the same «clinical characteristics have been seen as an integral and necessary part of the charism which has enabled her to be elevated to the highest levels of sanctity within the Roman Catholic tradition" (89-90). The historian Rudolph M. Bell embraces a similar perspective, launching a new, controversial, concept in his homonymous book, Holy Anorexia (Chicago: The University of Chicago Press, 1985). Thereafter, comparable approaches were proposed by historians and medical specialists alike. We can further indicate several studies on the particular case of Saint Catherine: M. Reda, G. Sacco, "Anorexia and the Holiness of Saint Catherine of Siena" Journal of Criminal Justice and Popular Culture 8/1 (2001): 37-47; F. Skårderud, "Hellig anoreksi. Sult og selvskade som religiøse praksiser. Caterina av Siena (1347-80)" [Holy Anorexia. Hunger and Self-harm as Religious Practices], Tidsskrift for Norsk Psykologforening [Journal of Norwegian Psychological Association] 45/4 (2008): 408-420; F. Espi Forcen, “Anorexia Mirabilis: the Practice of Fasting by Saint Catherine of Siena in the Late Middle Ages" The American Journal of Psychiatry 170/4, (April 2013): 370-371. A related type of inquiry claims that extreme asceticism, conjoined with intense, contemplative prayer, may lead to an alteration in the state of consciousness, providing us with a scientific ground based on neurosciences - for the saint's mysticism and ecstatic experiences. See J. Winchester, "Food of Angels: Fasting and Altered States of Consciousness in the Works of Catherine of Siena", manuscript, 2014, available online, https://www.academia.edu/16836908/Food_of_Angels_Fasting_and_Altered_States_ of_Consciousness_in_the_Works_of_Catherine_of_Siena (last accessed: December 1, 2017).

8 This is the main intendment of gender studies. Its most acknowledged representative is the historian Caroline Walker Bynum, whose seminal work cited above has the merit of retracing an extensive cultural context for medieval female piety, emphasizing the key importance of food, as both a metaphor and a practice within religious life. Food stands as the only resource women can control and, besides, they came to be associated with it and its metaphysical connection to physicality and particularly the corporeality and the humanity of Christ. Therefore, she rejects the modern "diagnosis:" "The notion of substituting one's own suffering through illness and starvation for the guilt and destitution of others is not symptom- it is theology." (206). The author also rejects the interpretation of women's asceticism as masochism or internalized misogyny, alleging that it was rather an exploration of the possibilities of their bodies. Just as Bynum, historian Joan Jacobs Brumberg - author of Fasting Girls: The History of Anorexia Nervosa as a Modern Disease (Cambridge, London: Harvard University Press, 1988) - is also indebted to a feminist creed; this is also the case of other (female) scholars of religious studies, like Daphne Hampson - Theology and Feminism (Oxford: Blackwell, 1990) - or 
ontological fact, inseparable from the mystical nature of her experience, and eventually of its theological significance. Observing Christ's example of absolute compliance with the plan of the Father - to the point of assuming death on the cross in order to atone for the sins of mankind -, by renouncing their will through an increasing ascetical training, the saints are given a renewed nature, on the strength of their complete immersion into the divine. Accordingly, their very physicality comes to be transformed, as they overcome biological limitations. Inside the religious environment of the Middle Ages, and mostly in hagiographic literature - all the more in early hagiographies, rather unmindful of the biographical precision of the saints' portrait ${ }^{9}$ sainthood is, first and foremost, a theological phenomenon, and no other explanation for its related occurrences would have been equally appropriate. We will therefore read it from the perspective of Christian anthropology, according to which the saint grows into an imago Christi. ${ }^{10}$ Although we assume that holy anorexia provides an inadequate, complete anachronistic exegesis, we cannot ignore the gender-related determinations and the historical dimension of devotional options, as well as sainthood paradigms. ${ }^{11}$ Thus, in order to allow a better

Sarah Coakley - for instance, Powers and Submissions: Spirituality, Philosophy and Gender (Oxford: Blackwell, 2002).

9 The French medievalist André Vauchez states that, during the early Middle Ages, hagiographers passed by the actual existence of saints and delineated "fragments of eternity." André Vauchez, "The Saint," in The Medieval World ed. Jacques Le Goff (London: Collins \& Brown, 1991), 313-325, especially 315.

10 According to Jaroslav Pelikan, the saint is a "reflection of Christic virtues." Traditia creștină. $O$ istorie a dequoltării doctrinei[The Christian Tradition. A History of the Development of Doctrine], (Iaşi: Polirom, 2006), vol. III Evoluţia teologiei medievale (6001300) [The Evolution of Medieval Theology (600-1300)], 200-201. Moreover, Olivier Clément asserts that humankind has a Christological hereafter, so much so that even the physical nature will become glorified, just like Christ's resurrected body. And it is the experience of sainthood that exemplifies the spiritualized corporeality, as part of the raised mode of the creature. See Olivier Clément, Riflessioni sull'uomo (Milano: Editoriale Jaca Book, 1991), especially 37, 105-107. Jacques Burr clearly points out that the transfigured, glorified body will transcend the limitations of the biological condition and also worldly existence -, yet not as a flight from matter, but a spiritualization of the whole being. Jacques Burr, Sens chrétien de l'histoire. Initiation au Mystère du Salut (Paris: Éditions P. Téqui, 1973), 368-372.

11 With regard to the specificity of the female religious experience and female sainthood, Bynum's Holy Feast remains the benchmark. The historical dimension of sainthood was substantiated in the work of Vauchez, Sainthood in the Later Middle Ages 
understanding of this case study, we will compare hagiographic texts to the saint's own vision, disclosed through her writings. We shall also complement our investigation with a diachronic perspective, taking into account earlier models emerged in the Franciscan milieu, namely Clare of Assisi - as a fasting saint - and Francis - as an alter Christus. Hereupon, fasting - as part of a wider range of austerities, but also associated with intense prayer and charity - is to be related to practices such as imitatio Christi and imitatio sanctorum, ${ }^{12}$ and eventually becomes a sign of the saint's Christification. ${ }^{13}$ In brief, Catherine's fasting will be scrutinized in manifold dimensions - ideological, historical, textual, and not least experiential -, with the purpose of capturing its meaning for the Catherinian milieu.

\section{Catherine's fasting within hagiographic accounts: towards a theological exegesis}

Hagiographic accounts praise the saint's virtues, among which the prodigious fasting occupies a central place. Raymond of Capua regards Catherinian abstinence as an exceptional achievement - comparable to the case of Mary Magdalene - which only proves the degree of

(Cambridge: Cambridge University Press, 1997). Despite its universalism, mysticism is also conditioned by the historical context, as proven by Peter Dinzelbacher - Christliche Mystik im Abendland. Ibre Geschichte von den Anfängen bis zum Ausgang des Mittelalters, Paderborn: Schöningh, 1994 - or Bernard McGinn - The Presence of God, 7 vol. (New York: Crossroad, 1991-2017).

12 These devotional patterns become fundamental in Western Christianity in the eleventh century, in the context of eschatological expectations following the Millennium. The ideal to retrace Christ's earthly life co-occured with a penitential trend, that upholded the ascetical precedent of the Desert Fathers. C.H. Lawrence, Medieval monasticism. Forms of Religious Life in Western Europe in the Middle Ages (New York: Longman, 1984), 247 sqq. Actually, for Catherine of Siena, the Desert Fathers represented a preeminent model. The Life, 26.

13 The concept is used on several occasions by the Italian historian Alessandra Bartolomei Romagnoli in referrence to Saint Catherine's case; see, for example: Alessandra Bartolomei Romagnoli, "La mistica, il dolore, la croce", Cultura e fede, 22 (2014): 100-114, especially 113; eadem, "Il corpo dell'estasi. Il lingaggio delle immagini dal medioevo al barocco" Donne nello specchio dell'Altissimo. Cuaderni di Arte, Cultura e Spiritualità (2014): 13-46, especially 39. It is also employed by María del Mar Graña Cid, who views Saint Catherine as a "feminine Christological model." María del Mar Graña Cid, "Mística feminina e semellanza das mulleres con Cristo. A propósito de santa Catarina de Siena" Revista galega de pensamento cristián 16 (maio-xuño 2009): 73-84, especially 84 . 
perfection God can impart to His saints. ${ }^{14}$ According to him, the saint gradually restricted her diet. At the age of six, when she received the first vision of Christ, she diminished her food intake, as she got solicitous about meditation and prayer. ${ }^{15}$ Afterwards, her sister's Bonaventura death led to Catherine's realization of the nothingness of the worldly existence; hence, at only fifteen, the girl embraced the aim of godlikeness. She would eat nothing but bread, raw vegetables, and water; furthermore, around the age of twenty she also renounced bread. Although the young woman had already been accustomed to unsavoury food, she had survived ever since on water, bitter herbs, and the holy host alone. ${ }^{16}$ In Caffarini's words, the saint discarded the levity of juvenile life - giving up wine, meat, and bread - as she passed under the guidance of the Holy Spirit and her life became miraculous. ${ }^{17}$

Whatever the psychosocial causes of Catherine's behaviour, we should not overlook the mental atmosphere of the time, dominated by the belief that sin has attracted God's wrath. ${ }^{18}$ Following the great plague and its devastating consequences, the conviction that repentance is the sole answer emerged. Under these circumstances, the penitential trend is reinforced; in fact, when she was seventeen or eighteen, Catherine herself joined such a community, called the Sisters of Penance, which forgathered devout lay women - especially widows who undertook pious practices according to the spirituality of Saint Dominic and fought together against temptation. ${ }^{19}$ The endeavour to

14 The Life, 27. Catherine herself had a special devotion for Magdalene, who lived in the desert for 33 years in a complete fasting, and also for Agnes of Montepulciano, another example of radical abstinence. See also Vita, 120.

15 The Life, 5-7.

16 Ibidem, 24,

17 Vita, 3-4.

18 Raymond also alleges that Catherine felt guilty about her sister's death and categorically refused to get married, pleading her cause through fasting. The Life, 13-16. In secondary literature, this aspect is emphasized as an option related to identity based on the allegiance that a life consecrated to God requires the repudiation of the sinful flesh. Bell, Holy Anorexia, 38-41; Bynum, Holy Feast, 167; Reda, Sacco, "Anorexia", 41 44.

19 The Life, 33, 36. Concerning the penitential ethos of the Dominican order, see William A. Hinnenbusch, Dominican Spirituality. Principles and Practice (Washington, D.C.: Our Lady of the Rosary Province, 1965), http://www.holyrosaryprovince.org/2011/media/essencial/dominican_spirituality.pdf, (accesed October 11, 2017). 
lead a holy life implied a battle against fleshly drives and earthly fondness through renunciation and asceticism. ${ }^{20}$ Alongside fasting, Catherine employed sleep and rest deprivation, using a couple of planks instead of a proper bed, vow of silence, voluntary mutilation - through flagellation, or the use of an iron chain which stung the flesh, causing severe pain -, together with continuous and fervent prayers and vigils. ${ }^{21}$ Ultimately, all of the saint's efforts prove their relevance within a Christic reference point: for late medieval believers, the self-inflicted pain of asceticism was a way of identification with the suffering of the incarnate Lord.22 All the more, as hagiographies are retrospective accounts, corporal mortifications are explicitly represented as means of preparing the union with the divine, that can only be attained through self-denial and detachment of the selfish will, which isolates man from God. Through the neutralization of the ego, and the assimilation of the individuality within the divine Oneness, a new person - inseparable from the latter - arises. $^{23}$

In fact, Christians consider the body is a creation of God, and is neutral by itself - it can mediate either grace or sin -, therefore its destination should be accomplishing godly ends. ${ }^{24}$ Towards the end of the High Middle Ages, Scholastic theology determined that sin occurs

20 C. Casagrande, S. Vecchio, "Păcatul" [The Sin], in Dicţionar tematic al Evului Mediu occidental [Thematic Dictionary of Western Middle Ages], ed. Jacques Le Goff, JeanClaude Schmitt (Iaşi: Polirom, 2002), 584-593, especially 588.

21 The Life, 25-26, 38. Vita, 4-5. The testimony of Augustin of Pisa Il Processo Castellano, 311.

22 See G. Klaniczay, "Illness, Self-inflicted Body Pain and Supernatural Stigmata: Three Ways of Identification with the Suffering Body of Christ," in Infirmity in Antiquity and the Middle Ages. Social and Cultural Approaches to Health, Weakness and Care, eds. Christian Krötzl, Katariina Mustakallio, Jenni Kuuliala (Farnham: Ashgate, 2015), 119-136, especially 124.

23 According to her confessor, Catherine received a vision of Christ in which he told her "Daughter, think of me and I will think continually on thee" and translates it as an admonishment to banish any personal thoughts, chiefly the concern regarding her own salvation. The Life, 44-45. See G. Cavallini, "La verità nell'ascesi cateriniana", (Rome: 1974), http:/ / www.centrostudicateriniani.it, (Last accesed: October 12, 2017).

${ }^{24}$ For the theological background, see K. Ware, "My helper and my enemy: the body in Greek Christianity," in Religion and the Body, ed. Sarah Coakley (Cambridge: Cambridge University Press, 1997), 90-110; see also Patricia Dailey, Promised Bodies. Time, Language and Corporeality in Medieval Women's Mystical Texts (New York: Columbia University Press, 2013), 2 sqq. 
when reason and will cannot compel concupiscence; ${ }^{25}$ consequently, it was compulsory to strictly control the body and subject it to the spirit, so that the latter might be freed from passions and disobeying the divine will. ${ }^{26}$ Concomitantly, medieval thinkers regarded women as being more likely to yield to the temptations of the flesh. Moreover, gluttony and lust were considered female vices par excellence and went hand in hand, so that renunciation of food and sexual intercourse were both prescribed as solutions to relinquish worldly satisfaction. ${ }^{27}$

Consequently, in order to have an authentic spiritual experience, women were expected to live secluded lives and undergo ascetic practices. Only when the Mendicant orders were founded with their openness to the lay society that women found more options for their religious aspirations - apart from becoming consecrated virgins although considerable austerities were still required. ${ }^{28}$ Within the Franciscan environment, women were given a model in the person of Saint Clare of Assisi (1194-1253). In her legend, female gender is described as the weaker one, so her example should serve as a guide for

25 Casagrande, Vecchio, "Păcatul”, 586-587.

26 See A. Louth, "The body in Western Catholic Christianity," in Religion and the Body, 111-130, especially 119; Marilyn Dunn, The Emergence of Monasticism. From the Desert Fathers to the Early Middle Ages (Oxford: Blackwell Publishing, 2003), 16. Early Christian ascetic literature - as the founding source of medieval asceticism - provides numerous accounts of the radical attitude towards the flesh, which is treated with outermost strictness, and even violence; despite this, the danger "comes through the body," it does not lie in the body, but in an undisciplined use of the body. R. von Thaden, "Glorify God in Your Body: The Redemptive Role of the Body in Early Christian Ascetic Literature," Cistercian Studies Quarterly 38.2 (2003): 191-209, especially 197-198.

27 C. Klapisch-Zuber, "Masculin/feminin" [Male/Female], in Dicţionar tematic al Evului Mediu occidental [Thematic Dictionary of Western Middle Ages], ed. Jacques Le Goff, Jean-Claude Schmitt (Iaşi: Polirom, 2002), 440-449, especially 445. In medieval anthropological reflection, the soul - regardless of belonging to a man or a woman was an image of God. Therefore, it was the body that engendered women's weakness. Nancy Caciola, Discerning Spirits: Divine and Demonic Possession in the Middle Ages (New York: Cornell University Press, 2003), 139, quoted by S. Hanson, "Connections between Body and Soul: the Asceticism of Medieval Saints," The UCI Undergraduate Research Journal XII (2009): 23-34, especially 25.

${ }^{28}$ Bynum, Holy Feast, 14 sqq. Whereas the model of female perfection was represented by the Virgin Mary and was inimitable, Mary Magdalene - the penitent saint - provided a more approachable option. Jacques Dalarun, Dumnezeu si femeia [God and the Woman] (Bucharest: Artemis, 2009), 67. 
surmounting this disadvantage. ${ }^{29}$ Hagiographic literature presents the saint as a tenacious fasting woman. In the canonization process, Clare's strict fasting appears to be a daily practice. She was so severe regarding food, that her mere survival seemed astounding to the fellow nuns who gave depositions on her holiness. ${ }^{30}$ There is a recurrent detail the witnesses refer to, namely the fact that three days a week - on Mondays, Wednesdays and Fridays - the saint ate nothing at all, whereas in the rest of the days she only took bread and water. ${ }^{31}$ Consequently, she became ill, thus Saint Francis and the bishop of Assisi urged her to eat on a daily basis; thereupon, Clare complies with this exhortation by virtue of the vow of obedience. In the bull of canonization issued by Pope Alexander IV, the motif of the three-day complete abstinence appears again, as well as a general sense of extreme frugality - so much so that it brought astonishment ${ }^{32}-$, along with many other austerities. ${ }^{33}$ Moreover, her unbelievable rigour, including her "continuous fasting, at every time of the year" is extensively addressed in the legend, which follows and expands the motifs in the

29 Preface to the legend, and also chapter $\mathrm{V}$ bis. As to the discussion about female religiosity in the context of the emergence of the Franciscan model, see Romagnoli, "Il francescanesimo femminile dalle origini al Concilio di Trento," in All'ombra della chiara luce, ed. Aleksander Horowski (Rome: Istituto storico dei Cappuccini, 2005), 13-18. The author emphasizes that women largely and actively partake the new religious movements, including the heretical ones that the Roman Church tried to overcome in the thirteenth century. Thereby, Clare was presented as an orthodox choice for female devotional needs.

${ }^{30}$ In the testimony of sister Pacifica, the following remark appears: "E disse che nei cibi era tanto stretta, che le suore si meravigliavano come il suo corpo vivesse." Il processo di Santa Chiara d'Assisi ed. Nelo Vian (Milano: Editrice Vita e Pensiero, 1962), 7. Furthermore, sister Amata assesses that the Saint appeared to be fed by angels and sister Balvina declares that her abstinence seemed impossible to be kept by a human being $(36,45)$.

31 Ibidem, 24, 36. In a slightly different version, sister Benvenuta claims that, during Lent and Saint Martin's Lent, Clare took but bread and water and a little wine on Sundays (15).

32 Bull of canonization 15, in Chiara Augusta Lainati ed., Fonti Clariane, 2012, 88, http://www.assisisantachiara.it/wp-content/uploads/downloads/2012/08/Fonti-

Clariane.pdf (Last accessed: March 1, 2017).

33 "aveva per letto la terra nuda e qualche volta dei sarmenti, e per guanciale un duro legno sotto il capo; era contenta di un'unica tonaca con un mantello di vile, rozzo ed ispido panno grossolano: e mentre con così umili vesti copriva il suo corpo, sulla nuda carne si cingeva talora di un aspro cilicio intrecciato con cordicelle di crine di cavallo." Ibidem, 88 . 
canonization process which were broadly recalled in the bull. ${ }^{34}$ Regarding her "admirable and inimitable" fasting, it further alleges the supernatural force that kept her alive, as well as her cheerful spirit and serenity that accompanied all her austerities. ${ }^{35}$

In Catherinian literature, fasting is taken to a whole new level. According to her main biography, Catherine was twenty five or twenty six when she became completely spiritualized, right after the mystical marriage to Christ occurred. Her bodily functions were entirely modified, so she would begin to live in a supernatural manner, being freed from the need to consume food. ${ }^{36}$ Her new ontological state was attained as a consequence of literally tasting the blood of the side wound of the Crucified during an ecstatic rapture; this came as a reward for overcoming the disgust she had previously faced while grooming a woman's festering wound. ${ }^{37}$ Thenceforward, Catherine would be permanently and intimately connected to her divine Spouse and her life would become a constant sequence of ecstasies and miracles. ${ }^{38}$

34 The legend I, XI 17, in Sainte Claire d'Assise. Sa Vie par Thomas de Celano. Ses Écrits, ed. Damien Vorreux (Paris: Éditions Franciscaines, 1953), 34-35.

35 Ibidem, XI 18, 35-36.

36 According to Raymond of Capua, Christ told Catherine: "I will diffuse in thy soul such an abundance of grace, that thy body itself will experience its effects and will live no longer except in an extraordinary manner..." The Life, 96, and further 98-102. See also the opening quotation. On his turn, Caffarini reads Catherine's prodigious abstinence as an effect of a divine intervention, namely the sacrament of absolution administered to the Sienese virgin by Christ himself during an ecstasy. Supplemento at Vita ed. Tantucci, 118 sqq. As to the nuptial experience - the incident that foreshadowed the mystical union -, see The Life, 57-59.

37 Ibidem, 86-87, 93-94. As Raymond notes, Christ approached Catherine with the following words: "Never hast thou been dearer or more pleasing to me - yesterday in particular thou didst ravish my heart. Not only didst thou despise sensual pleasures, disdain the opinions of men, and surmount the temptations of Satan, but thou didst overcome nature, by joyfully drinking for my sake a loathsome, horrible beverage. Well, since thou hast accomplished an action so superior to nature, I will bestow on thee a liquor above nature. [...] Drink, daughter that luscious beverage which flows from my side, it will inebriate thy soul with sweetness and will also plunge in a sea of delight thy body, which thou didst despise for love of me." Consequently, Catherine applies her mouth to the wound: "she drank long and with as much avidity as abundance; in fine, when our blessed Lord gave her notice, she detached herself from the sacred source, satiated, but still eager...”

38 In this regard, Catherine experiences mystical phenomena such as the exchange of hearts with Jesus - leading to an essential coalescence, to an identity of thoughts -, the stigmatization, the mystical death (motif which will be reopened below) and even 
For medieval christocentric religiosity - particularly within female piety -, the ability to survive without earthly food implies the accession to a supply of spiritual nurture, materialized by the holy host. ${ }^{39}$ At this point, some contrasting details come to light, which may be regarded as a mere tribute to the fact that human memory is only relatively accurate; furthermore, we assume it samples the veridicity of the recounted events, which definitely appear as something else than a stereotypical recurrence. ${ }^{40}$ Catherine's primal complete fasting is related in the sources to the feast of the Ascension of the Lord. ${ }^{41}$ In the day of

levitation. I have addressed this topic in my article "Carne mizerabilă sau icoană vie? Trupul în viziunea sfintei Ecaterina de Siena şi a Caterinati” ["Miserable Flesh or Living Icon? The Body in the View of Saint Catherine of Siena and the Caterinati'], in Fragmente din trecut. Tinerii cercetători și istoria ["Fragments from the Past. Young Researchers and History"], ed. Anamaria Macavei and Diana Maria Dăian (ClujNapoca: Presa Universitară Clujeană, 2015), 59-72.

39 Brumberg, Fasting Girls, 41-42.

${ }^{40}$ For instance, the statement above has to be nuanced in the sense that Catherine was seen going without normal food for long periods of time. Raymond of Capua recalls that she confessed to him: "'God satisfies me so), she answered, «in the holy Eucharist, that it is impossible for me to desire any species of corporal nourishment." The Life, 102. Thomas Caffarini is slightly temperate when he claims that the saint survived for weeks, even for months on the host alone, and by the end of her life she lived in this condition for almost a year. Similar assertions appear in various testimonies given in the canonization process: see Il Processo Castellano: depositions of Steven Maconi, 237; Francis of Lucca, 315; Peter of Giovanni Ventura, 356-357. Francis of Lucca, for instance, did not personally meet the saint, but he specifies he had learnt from trustworthy people that Catherine's frequent communion allowed her to forgo any other food but the host. Such a perspective - indicative for the way in which the Catherinian model was disseminated and receipted - stresses even more the importance given to the saint's prodigious abstinence. Once with the canonization bull issued in 1461, pope Pius II - a Sienese himself - officially sanctions the sanctity of his fellow citizen and acknowledges Catherine's asceticism, drastic fasting and prodigious abstinence. On the latter aspect, the bull assumes that the saint sometimes fasted from Ash-Wednesday until the Ascension, surviving on the Eucharist alone. For not less than eight years, she had been eating nothing but some juice of herbs, "which she could not even retain on her stomach;" for her, eating was a punishment and the Holy Communion was a celestial banquet. Bull of Pius II, Appendix, 400-401.

41 Raymond of Capua indicates a twelve week term, beginning with the Lent, while Bartholomew Dominici offers as inaugural milestone Passion Sunday and refers to a fifty-day time span. The Life, 101; supplementary specifications at Dominici's testimony, Il Processo Castellano, 283. However, this was not the only contradiction: Raymond claims the saint kept her strength and mood throughout that time, but Bartholomew points out Catherine's exhaustion and faintness, as she was afraid that she would either die or start a whole new, miraculous way of life. As for Thomas Caffarini, he speaks of a fifty- 
observance, Catherine ate bread and vegetables, than she proceeded with her fasting, in an almost uninterrupted course from then on. The Eucharist became her main food and equally her provision of divine grace, which infused her entire being, ensuring inclusively energy for her body. ${ }^{42}$ Practically, the mindset according to which the soul can influence the body - as the human being was conceived as a psychosomatic unity - entails the belief that spiritual plenitude can compensate bodily shortage. ${ }^{43}$ For that matter, the miraculous fasting of the Sienese saint serves - according to her confessor - as an objective demonstration for the biblical assertions that "Man shall not live on bread alone, but on every word that comes from the mouth of God" (Matthew 4:4) - Christ being the Word of God, whose actual body is consumed as the host -, respectively "The righteous will live by faith" (Romans 1:17). ${ }^{44}$ In a similar manner, Thomas Caffarini states that Catherine's miraculous survival was a way through which God displayed his almightiness. ${ }^{45}$

Indeed, late medieval mysticism connects the world to the supernatural, as the mystic embodies God's message, concurrently prefiguring the promised everlastingness through their faultless life. ${ }^{46}$ From a theological point of view, sainthood - as a universal vocation follows the communion between the Saviour and his Church, invited to partake of his glory as he partook in our humanity, thus allowing the possibility that all human beings be deified. ${ }^{47}$ Consequently, the

five day abstinence during Lent without any negative effects on her health. Supplemento, 187-188.

42 The Life, 101-102. The respective state is thus described by her confessor: "deprived of all exteriorly, but abundantly nourished in the interior." (102)

43 Caroline Walker Bynum, "The Female Body and Religious Practice in the Later Middle Ages" in Fragmentation and Redemption: Essays on Gender and the Human Body in Medieval Religion (New York: Zone Books, 1991), 181-238, especially 222. The high and late Middle Ages advanced a new focus on the spiritual, in close connection to the belief in the soul's ability to influence the body. Hanson, "Connections," 26.

44 The Life, 101.

45 Supplemento, 187.

46 See Peter Dinzelbacher, Vision und Visionsliteratur im Mittelalter (Stuttgart: Anton Hierseman, 1981), chapters 12-16, quoted by B. McGinn, "The Changing Shape of Late Medieval Mysticism,” Church History 65/2 (Jun. 1996): 197-219, especially 215.

47 Pelikan, Tradiția creștină [Christian Tradition], 200-201. In the matter of medieval views on the theme of deification - very present in the writings of religious women -, see Thomas A. Fudgé, Medieval Religion and its Anxieties. History and Mystery in the Other 
Christified saint becomes a living replica of the earthly biography of the Saviour, but also of his divine nature that overrules the limitations of human existence. Furthermore, medieval Christianity professes a strong assurance that heavenly-like incorruptibility might be reached ahead of time, as proven by the perfect conservation of holy relics and the divine power they comprise, but also through the living saints' miraculous survival without food, the cessation of excretions, as well as any phenomena defying biological functions. ${ }^{48}$ As a matter of fact, the main Christian thinkers proclaimed - based on the prospect of the Apocalypse 7:16 - that living in Paradise presupposes the remission of physiological necessities such as hunger, thirst or sleep, the perdurable hungerlessness as a glorious fasting becoming a privilege of the eternal beatitude. ${ }^{49}$ In this context, the previously mentioned theme of Catherine's mystical feeding - the Saint being offered to drink the blood from Christ's side wound - is presented by Raymond of Capua as an example of heavenly feeding; it was thought that within the realm of the blessed nurture is faultless, since a spiritual and miraculous nourishment ensured an endless delight and a full satisfaction, yet never induced a sense of saturation..$^{50}$ In a similar manner, Thomas Caffarini remarks that the privilege of being exempted from bodily demands is granted to those few perfect ones that are mentally united to God, which fact allows the release from lower functions. ${ }^{51}$

Against this background, the saint's supernatural subsistence evinces its full meaning only in relation to the Christic model she follows and into which she gets to be absorbed. ${ }^{52}$ Around 1370, when she was

Middle Ages (New York: Palgrave Macmillan, 2016) chapter "Sensuality, Spirituality, and Sexuality in the Religious Experience of Female Mystics", 157-181, especially 170-171.

48 Bynum, “The Female Body", 194.

${ }^{49}$ For that reason, fasting may be practiced in order to obtain a temporary liberation from the fleshly constraints, approximating the practitioner to the angelic condition. $G$. Ledda, "Cibi del Paradiso," in Banchetti letterari, ed. G. M. Anselmi and G. Ruozzi (Rome: Carocci, 2011), 118-125, especially 119, 123.

${ }^{50}$ Ibidem, 121. This is how Raymond resumes the presentation of the respective episode: "in fine, when our blessed Lord gave her notice, she detached herself from the sacred source, satiated, but still eager, because she experienced no repletion at being satiated, nor pain at still desiring." The Life, 94.

51 Caffarini's deposition, Il Processo Castellano, 126.

${ }^{52}$ Catherine's life is presented in her legend as a faithful copy of the Gospel, as the saint is identified with Christ through the mystical marriage, respectively through suffering. Cid, "Mística feminina," 74. 
twenty three, the Lord commissioned her to launch into public activity, ${ }^{53}$ initiated with charitable deeds - such as giving her own garments, distributing food or taking care of the sick and destitute. ${ }^{54}$ Later on, the saint would be able to perform miracles related to Christological precedents: sinners were converted and eventually saved due to her prayers, physical ailments were cured, demons were exorcised and so on. ${ }^{55}$ Furthermore, Raymond's description of the metamorphosis of Catherine's face - which assumes the features of the Saviour in a moment when her confessor was doubting the source of her revelations - is particularly illustrative for the theme of the saint's Christification, a leitmotif in the legend. ${ }^{56}$

In this respect, within the context of the rivalry between the two main mendicant orders, Saint Catherine may be compared to Francis of Assisi, whose Christification was substantiated by the reception of the stigmata. ${ }^{57}$ As a matter of fact, Catherine's stigmatization notwithstanding that it was sanctioned and venerated in the Dominican devotional environment - has been disputed, precisely because bearing

53 Despite the fact that, within medieval society, women were kept away from public affairs, in the later Middle Ages - particularly in the fourteenth century - female saints, mystics for the most part, benefited from favourable conditions for recognition. Within the context of the moral and institutional crisis of the Church, saintly women were regarded as the only ones worthy of receiving messages from God in a realm of (male) corruption. This was due to their strong religious commitment - partaking of Christ's redemptive suffering - and their detachment from worldly pursuits. Vauchez, Sainthood, 384.

54 The Life, 61-62 sqq.

55 Ibidem, 152 sqq, 167 sqq, 182 sqq, 187 sqq.

${ }^{56}$ Cid, "Mística feminina," passim. For the aforementioned episode, see The Life, 43.

57 This episode of Francis' life is present in all of his primary biographies - Thomas of Celano's Vita prima (II, III 94-95) and Vita secunda (II, XCVIII 135), respectively Legenda major (XIII) and Legenda minor (VI 1) written by Bonaventura of Bagnoregio. The following editions were consulted for this study: Thomas de Celano, Vie de Saint François d'Assise, ed. Damien Vorreux, (Paris: Éditions Franciscaines, 1952) and S. Bonaventura, Legenda maior S. Francisci Assisiensis et eiusdem Legenda minor, (Florence, Quaracchi: Typographia Colegii S. Bonaventurae, 1941). Further on, it has been noticed that there is a predilection towards relating Catherine's life to male models of sanctity (like Saint Dominic) as she was making her way through public life, at least in her main hagiography. Nevertheless, rigurous fasting is based on female precedents. Cid, "Mística feminina", 78, 81. Moreover, as Gábor Klaniczay shows, it is at the level of female religious experience that the model of Saint Francis - based on the pathematic understanding of Christ's suffering - is followed to the ultimate consequence of personally assuming the redemptive passions. See "Illness", 127 sqq. 
the Lord's holy wounds had been recognized as an exclusive prerogative of Saint Francis. ${ }^{58}$ The Sienese saint's likeness to Christ noticeable through her way of living and especially her readiness to suffer, as well as through the mystical phenomena which marked the route of her fusion with the Lord - also indicates the arrogation within the Order of Preachers of the special blessing which God endowed upon their religious community, as a response to the similar assumption made by the Franciscans. Regardless that Francis might have assumed a rather feminine path - as Jacques Dalarun suggests ${ }^{59}$ - we presume it was the theological significance of his experience, namely his transformation into an alter Christus, that prevailed at that time. And this is what the Dominicans emulated.

On the same note, Catherine's new ontological level states under the sign of the redemptive mission she was entrusted; thereby, the freewill imitation of Christ by means of ascetical practices was followed by the divine privilege to atone for her fellow's sins and make amends for the sake of the Church. ${ }^{60}$ This undertaking primarily arose as imitatio Christi, where suffering becomes the paramount experience. ${ }^{61}$ This the

58 Thomas Caffarini actually claimed the superiority of Catherine's stigmata, which only remained invisible due to her modesty. Lemeneva, "The Borders", 197. See also Romagnoli, "La disputa sulle stimmate," in Virgo digna coelo. Caterina e la sua eredità. Raccolta di studi in occasione del $550^{\circ}$ anniversario della canonizzazione di santa Caterina da Siena (1461-2011), ed. eadem et all. (Vatican City: Libreria Editrice Vaticana, 2013), 407-446; Tamar Herzig, "Stigmatized Holy Women as Female Christs," in Archivio italiano per la storia della pietà XXVI (2013): 151-175, especially 158.

${ }^{59}$ Dumnezeu si femeia, 147 sqq.

${ }^{60}$ See The Life, passim, for instance: [Christ told Catherine] “... but thou shalt expose thyself to every species of fatigue in order to save their souls. Follow therefor courageously the inspiration which will enlighten thee; for I shall draw, by thy aid, numerous souls from the gulf of hell, and I will conduct them, with the help of my grace, to the kingdom of heaven." (96-97); "I have already promised thee, and I do promise thee to reform the Church my Spouse, by the sufferings of my servants, whom I invite to expiate in union with thee, by sorrows and weeping, the iniquity of her ministers." (256).

${ }^{61}$ For instance, the legend mentions that, during an ecstatic dialogue with her Spouse, the saint has chosen the crown of thorns instead of the crown of gold: "Lord,> replied Catharine, ¿I have long since renounced my own will, and have promised to follow thine in all things: hence I have no choice to make but if thou wilt have me to answer, during this life, I desire to be conformed to thy blessed Passion, and find my chief delight in suffering with thee.) Saying this she took the crown of thorns with both hands, as the Saviour presented it to her, and pressed it on her head with so much violence that the thorns entered on all sides. She felt the wounds sensibly after the 
interpretative key which upholds the salient allegations on the saint's inedia, according to which any attempt to eat can cause her tremendous distress. ${ }^{62}$ This burden is manifestly not a feature of the glorified corporeality. Christ's body kept its historical dimension and concreteness after the resurrection, while being nonetheless spiritualized, acquiring the conditions of impassibility, subtlety, agility, and clarity, which the good will subsequently share with him - "He will reform the body of our lowness, made like to the body of His glory" (Philippians 3:21). Thereby, the Lord could eat with the disciples, although not needing to (Luke 24:41-43, John 21:13). ${ }^{63}$ Thus

vision, as she herself informed me." The Life, 89. Elsewhere: "My great consolation is to suffer, because I am aware that by suffering I shall obtain a more perfect view of God." (141-142). In his turn, Bartholomew Dominici shows that Catherine considers herself united to Christ in suffering. Il Processo Castellano, 273.

${ }^{62}$ Caroline Walker Bynum suggests that Catherine took the challenge as a divine favour. Holy Feast, 169. "When she was obliged to take food, she was so incommoded that it would not remain in the stomach and it would be quite impossible to describe her grievous pains on such occasions."; "her stomach could digest nothing, and rejected whatever was taken into it; she afterwards suffered the most terrible pains, and her whole body appeared to be swollen she did not swallow [...] every day, she was forced to throw up what she had taken, and that with so much difficulty, that it was necessary to assist her by every possible means." Raymond of Capua resumes that the saint's new condition raised suspicions, and her incredible living was deemed a possible temptation of Satan. Therefore, her confessor at that time, Thomas della Fonte, ordered her to eat. She obeyed by virtue of obedience, but it brought her on the brink of death. In these conditions, Catherine convinced her confessor that eating for her was a veritable suicide, for which reason she was allowed to persevere in her fasting, as Thomas became assured this was God's will. The Life, 95, 98-99, 108. On top of that, the testimonies in the canonization process offer supplementary details. See, for example the illustrative account of Francis Malavolti: “...prendeva un po' di insalata e di erbe crude o un po' di frutta e dopo avere masticato tali cose le restituiva di nascosto dalla bocca. [...] In questa operazione la vergine soffriva talmente che la sua faccia appariva tumefatta, tale era la sofferenza per fare uscire quel liquido da ogni punto dove fosse giunto. Il procedimento era il seguente, e cioè era necessario che essa si appartasse con una delle sue compagne, bevesse aqua fredda e poi con una pagliuzza di fieno o con una piuma, introdotte nella gola, con intollerabile pena, provocasse il vomito di tutto ciò che era entrato nello stomaco." Il Processo Castellano, 337. In his turn, Steven Maconi declared to have repeatedly witnessed the saint throwing up blood and if she could not eliminate whatever food or drink she had ingested she would eventually faint. Ibidem, 237.

63 The aforementioned qualities are unravelled by Thomas Aquinas, one of the major theological authorities of the Middle Ages, all the more in the Dominican milieu from which he came. See Summa Theologiae, trans. by Fathers of the English Dominican 
Catherine's inability to feed herself in a natural manner was - as paradoxical as it may sound - rather a token of her earthliness. More precisely, she still belonged to the sinful world by means of her biological body - which experienced degeneration and ultimately resulted in death ${ }^{64}$-, so pain was to be embraced as an unavoidable part of the fallen state. Nevertheless, we must consider that medieval female religiosity and mysticism is primarily associated with and - from the part of its protagonists - focused on the humanity of the Lord, so that saintly women relate themselves to the suffering Christ, through mortification of the flesh. Under these circumstances, Catherine of Siena is to be compared to the crucified Christ, which is why her ascetical strain and the general relevance of pain within her piety are reported to increase as she advances in the mystical union. ${ }^{65}$ Nevertheless, the assimilation of the human nature of the Word will ultimately lead to a participation in His glory. ${ }^{66}$

In any case, Catherine's inedia is chiefly a manifestation of a personal condition. In this regard, Bartolomeo Dominici's testimony is particularly eloquent: he declares that the saint imputed herself the vice of gluttony and saw in her disability a favourable answer to her prayer of being punished for it. ${ }^{67}$ As a result, she decided to eat once a day along with the other members of her religious community to counteract the scepticism surrounding her incredible lifestyle. She was in pain every single time, but endured it as an opportunity to expiate her sins. ${ }^{68}$ Accordingly, the saint saw her torment as an act of justice. ${ }^{69}$

Province, online ed. Kevin Knight, 2016, http://www.newadvent.org/summa/5.htm (Last accessed: December 4, 2017), Third Part, question 54, 55 (especially art. 6, on the episode of Christ dining with his disciples); Supplement to the Third Part, q. 82-85. Besides, Aquinas states that the resurrected body would need no food because of its immortality. Ibidem, q. 81, art. 4.

${ }^{64}$ In the legend, her condition before she died is thus described: "She appeared to die, because the gross sense of mankind did not descry her glory". The Life, 238-239.

65 Cid, "Mística feminina," 78.

${ }^{66}$ Raymond reveals that God told the Sienese virgin "the more thou wilt suffer for me, the more thou will be like me, and... the more thou wilt resemble me in sufferings, the more, also, thou shalt be like unto me in grace and glory." The Life, 9.

67 Supplementary specifications at Bartholomew Dominici's testimony, Il Processo Castellano, 284-285. Raymond also says that the saint was convinced that her state was a consequence of her infinite trespasses. The Life, 105-106.

68 "....she answered those who asked her why she took no nourishment - 〈God, said she, «on account of my sins, has stricken me with this infirmity which prevents me from 


\section{An inner perspective on supernatural sustenance}

I have already pointed out that extreme fasting as a proof for sanctity becomes a central topic in hagiographic literature. ${ }^{70}$ In Catherine's case, confronting the hagiographic texts with the saint's own writings namely her letters, a theological treatise entitled The Dialogue of Divine Providence, and a small collection of prayers ${ }^{71}$ - suggests that it captures the interest of the saint as well, and in a truly personal manner. Indeed, this only enhances a sense of genuineness regarding that particular practice. At first view, fasting does not seem a major concern for Catherine - ascertainment that applies to Clare as well - and she even recommended moderation to some of her correspondents. ${ }^{72}$ Conversely, we have seen the extent to which the testimonies on her life reflect the respective aspect of Catherinian religious pattern. This apparent inconsistency is explainable if we take into account that the two types of sources do not belong to the same genre, thus having different aims, and being addressed to different audiences: ${ }^{73}$ in the first place, the saint's writing is rather abstract and highly impersonal; ${ }^{74}$

taking food; I desire to eat, but it is impossible.)" She furthermore refers to "the great grace $\mathrm{He}$ accords me of allowing me to make satisfaction in this world." Ibidem, 105$106,108$.

69 "Come, let us do fit justice to this miserable sinner." Ibid., 108. "Perciò essa chiamava questo quotidiano supplizio di vomito «santa giustizia." supplementary specifications at Dominici's testimony, Il Processo Castellano, 285. The same notion is evoked by Steven Maconi, respectively Francis Malavolti $(238,337)$.

70 Bynum, Holy Feast, 83.

71 The following editions were used: Lettere di Caterina da Siena, ed. P. Misciattelli (Florence: Marzocco, 1939); S. Caterina da Siena, Il Dialogo, ed. Giuliana Cavallini (Siena: Cantagalli, 1995); S. Caterina da Siena, Le Oraz̧ioni, ed. Giuliana Cavallini (Rome: Edizioni Cateriniane, 1978).

72 Lettere CLXXIV, 539; CCXIII, 659. As to Saint Clare, see Medieval Women's Latin Letters, letter 569 (37, 40), https://epistolae.ccnmtl.columbia.edu/letter/569.html (Last accessed: October 11, 2017).

73 This aspect is particularly made clear by David F. Tinsley, in relation to Catherinian asceticism. See The Scourge and the Cross: Ascetic Mentalities of the Later Middle Ages (Leuven: Peeters, 2010), 3.

${ }^{74}$ The Dialogue is conceived as a revelation of the divine wisdom, disclosed by God to an impersonal soul and by way of the letters, the saint gives advice regarding spiritual and sometimes even practical issues. In fact, within the Abrahamic tradition, mystics may regard themselves as simple messengers of the Lord (although an autobiographic mystical discourse also emerges in the Middle Ages ). Anthony J. Steinbock, Phenomenology and Mysticism: The Verticality of Religious Experience (Bloomington, 
furthermore, she did not promote her lifestyle, which she found as beyond her own agency. In general terms, Catherine is silent about her experience, but she makes an exception when it comes to her inability to eat according to nature. More than that, one alarmed devotee inquired about her health, which clearly reveals the fact that the unparalleled circumstance was an undeniable reality in the Catherine's environment, not merely a metaphor or a cliché.

The saint's answer provides us with an inner look on her inedia. Catherine confessed she would want to eat like everyone else and she has been praying and constantly struggling to achieve that goal. ${ }^{75}$ The saint described her condition as an illness (infirmita $\hat{\text { ) }}$ and suggested therewith that it could have resulted from a demonic deception; nevertheless, she hoped it was god-sent, to help her suppress the vice of gluttony, which she could not correct on her own, to her great misery. ${ }^{76}$ In Catherine's view, any disability has a spiritual component, but simultaneously involves pain, which is an opportunity to follow the way of the cross. ${ }^{77}$ And under the fulcrum of the cross - ergo the lead of Christ -, the demon would have no power over her. ${ }^{78}$ In a reciprocal manner, the same emphasis on the dialectics between the divine and the diabolical is present in Raymond's biography and also in Caffarini's work. ${ }^{79}$ Despite the fact that the saint never completed her struggle nor sormounted the tension resulting from the relentless awareness of the fallen state - so that she was constantly mindful of the abiding

Indianapolis: Indiana University Press, 2007), 241-242; McGinn, "The Changing Shape", 213.

${ }^{75}$ Her words are highly eloquent: " $\mathrm{E}$ io vi dico, padre mio, e dicovelo nel cospetto di Dio, che in tutti quanti e' modi che io ho potuto, sempre mi sono sforzata, una volta e due il dì, di prendere il cibo; e ho pregato continuamente, e prego Dio e pregherò che mi dia grazia che in quest'atto del mangiare io viva come le altre creature, se egli è sua volontà, perocchè la mia c'è." Lettere XCII, 290.

${ }^{76}$ Lettere XCII, 289-290.

77 Ibidem, CCCXIV, 1008.

78 "Ma io mi rivolgo, poi, e appoggiomi all'arbore della santissima croce di Cristo crocifisso, e ine mi voglio conficcare; e non dubito che s'io sarò confitta e chiavellata con lui per amore e con profonda umiltà, che le dimonia non potranno contro di me, non per mia virtù, ma per la virtù di Cristo crocifisso.” Ibid., XCII, 290.

79 The Life, passim, especially 98 sqq (regarding the suspicions raised by the saint's inability to eat); Supplemento, 187 (on the same topic). 
intrusion of the devil ${ }^{80}$-, her entourage concluded that her extraordinary condition must have been enabled by God. For instance, Thomas Caffarini claims that Christ validated Catherine's conduct and even confirmed to the saint that her peculiar sustenance has been happening in agreement with His will; moreover, she would have been encouraged to persevere. ${ }^{81}$

Returning to the previous idea, can thus distinguish the saint's own statement with respect to the value of pain and of imitatio crucis withal, so much so that her allegiance to the humanity of Christ can be asserted, reinforcing the assignments of those who bear witness of her godlike existence. ${ }^{82}$ To resume, suffering is for her a path towards heaven - based on the fact that the salvation of humankind was mediated by the cross -, an experience at the intersection between divinity and humanness. ${ }^{83}$ Longing for God cannot be separated from the disposability of enduring pain for His sake and for the service of one's fellows; hence agony is a proof of the greatest love and is pleasingto the Lord. ${ }^{84}$ In the end, this reflection may be regarded as

${ }^{80}$ Catherine wascontinuously tormented by demonic temptations, which she countered with the increasing sternness of her way of life. The Life, 50-51.

81 "Figliuola mia, non mancare di confidenza; le opere tue sono a me molto grate, ed accette; prosegui con perseveranza, e quiete di animo in esse." Supplemento, 95. As to Raymond's doubts and eventual conviction that Catherine was acting under God's consent, see footnote 59 .

82 Catherine had been asking God for the permission to suffer for the salvation of her neighbour. Il Dialogo II, 2; Le Orazioni XIV, 19; XXVI, 30; Lettere CCCXXXI, 1065. Nevertheless, her main exhortation in the letters adverts to the compliance with the crucified Christ ("conformarsi con Cristo crocifisso").

${ }^{83}$ See Il Dialogo IV, V. Catherine proclaims that it was the Saviour who, through the sacrifice of the cross, professed the attitude of disregard to his will, respectively hatred against wicked flesh and scourging the body in order to give satisfaction for the original sin. Le Orazioni I, 1; Lettere CCXCIX, 943-944. Moreover, God tells the saint that, as a consequence of the inherent imperfection of human condition, man cannot be acquainted with God only through suffering. Il Dialogo LXXXIII, 72. I have formerly discussed the question regarding the prominence of suffering for the Sienese saint in "What Else," 142-143.

84 "Molto e piacevole a me il desiderio di volere portare ogni pena e fadiga infino alla morte in salute dell'anime. Quanto l'uomo più sostiene, più dimostra che m'ami: amandomi più cognosce della mia veritá e quanto più cognosce più sente pena e dolore intollerabile dell'offesa mia." Il Dialogo V, 5. "E chi molto ama molto si duole, unde a cui cresce amore cresce dolore." (CXLV, 154). 
Catherine's affirmation of the ascetical option her biographers speak about. ${ }^{85}$

In connection to the question of the saint's struggle, one further clue regarding the actual complementarity between her attitude and her disciples' hagiographic perspective may be remarked. According to Steven Maconi, Catherine uncovered her motivation to persist in the exhausting process of forcibly eating and purging: besides the conviction that she was given the chance to correct the vice of gluttony, and the determination to respond to those outraged by her striking subsistence, by means of her perseverance she avoided being completely distracted from her earthly existence, ensuring her body would not get unfeeling. ${ }^{86}$ It should be stressed that, as a result of the new ontological level she had reached, the saint was perceived as being in a permanent state of ecstasy, in other words, as literally living in the spiritual realm. ${ }^{87}$ While the devotees considered her a rather celestial being, in the light of Maconi's declaration, Catherine proves to be aware that she had to abide in the via crucis of the earthly, bodily existence. Thus she continued to pursue Christ's passions instead of delighting in his glory that had already been revealed to her in a threeday vision equivalent to a mystical death, through which she was allowed to directly contemplate heavenly reality. ${ }^{88}$ Although the body -

85 In the saint's opinion, the flesh has to be restrained, in order to annihilate the selfish perverted will and comply with the will of God. See Lettere CCLXXXVII, 906: "però la ragione con libero arbitrio, e con la santa e buona volontà, si leva con odio e dispiacimento, macerando il corpo e la carne sua, e occidendo la propria volontà col coltello della santa obedienzia."; CCXCIV, 927: "la miserabile carne [...] domarla col digiuno e vigilia e continua orazione...”.

86 This last reason is thus presented: "la mente, per mezzo di questa pena corporale, torna ad occuparsi del corpo; altrimenti essendo la mente sempre così assorta, il corpo rimarrebbe insensibile." Testimony of Steven Maconi, Il Processo Castellano, 238.

87 In this regard, besides the details previously specified (see footnote 38), we shall append one more eloquent assertion of Raymond of Capua: "As soon as the thought of Jesus penetrated her mind, the soul appeared to retire from the sensual part, and the extremities became cold, contracted, and insensible. During her ecstasies, she was often lifted above the earth, her body pursuing her soul, in order to shew the power of the spirit that attracted her." The Life, 65.

88 "her spirit was so absorbed in the contemplation of heavenly things, that during three days and three nights her body remained insensible; several persons present thought that she was dead, or at the point of death. Others better informed, believed that she was ravished with the Apostle [Paul] to the third heaven. When the ecstasy had terminated, her mind remained so filled with the remembrance of what she had seen 
upon which she projected a negative image, referring to it as an imprisonment of the true self, namely the soul ${ }^{89}$ - turned out to be an impediment to the complete union with the divine Spouse, ${ }^{90}$ the saint nevertheless assumed her corporeality. We presume this is due to the fact that it enabled her to cultivate pain in imitation of Christ and to carry on this way the Saviour's expiatory undertaking.

In another train of thoughts, we have particularized how the Sienese virgin was told to have survived completely devoid of proper food; in fact, Catherine appears to be committed to the possibility that spiritual nourishment may substitute the material altogether. For instance, the saint points to the fact that the Eucharist is the actual "bread of life,", that God gave mortals in order to fortify them during their journey through this transient life. ${ }^{91}$ For medieval Christianity, the perception according to which the body and the soul were indivisible and thus complementary resulted in the inference that the flesh is also part of the divine plan and it will eventually resurrect along with the soul, in a glorified state. ${ }^{92}$ In addition, as it ensues from the conception of Saint Paul the Apostle, the body is more than a biological entity: it is conjoint with a spiritual faculty that intercepts the divine grace, so that a conduct concordant to God's will may be assumed, and mirrors its impact on the human being. For that reason, Pauline anthropology - which exert a considerable influence on Catherinian thought, since the epistles are repeatedly quoted in her writings - establishes an antithesis between a living according to the flesh and a living according to the Spirit (Romans 8); the latter is the ultimate aim of Christian existence and

that she returned with difficulty to things of earth, and remained in a kind of slumber or ebriety from which she could not be aroused." Ibidem, 127.

89 Il Dialogo CXLV, 154: "stando nella carecere del corpo..."; CLXVII, 185-186: "desidera l'anima mia d'escire della carcere del corpo tenebroso..."; Lettere: CLXXXIX, 581-582: "l'uomo, mentre che vive nella carcere corruttibile del corpo suo (il quale è una legge perversa, che sempre lo invita e inchina a peccato)". I have also emphasized this anthropological understanding of the saint in "What Else," 141.

90 Cid, "Mística feminina," 77.

91 Il Dialogo CXI-CXII, 104; CXXXV, 140.

92 For the medieval conception on the posthumous fate, see Bynum, "Material Continuity, Personal Survival, and the Resurrection of the Body: A Scholastic Discussion in Its Medieval and Modern Contexts," in Fragmentation and Redemption, 239-298, and eadem, The Resurrection of the Body in Western Christianity, 200-1336 (New York: Columbia University Press, 1995). 
brings to light the transformative potential of the body. ${ }^{93}$ Not coincidentally, Catherine's new ontological condition highlighted in hagiographic texts was secured through a triumph against the fleshly response that interfered with her holy undertaking. ${ }^{94}$

Furthermore, as the Dialogue introduces the miracle of multiplication of loaves performed by Saint Agnes of Montepulciano, eating is designated as a vital need of the imperfect, leaving room for a feasible unearthly subsistence; through this, the saint shares Raymond's aforementioned enunciation - based on the Scripture - with respect to the transformation of man's life according to the spirit. ${ }^{95}$ As an ensuing elucidation, Catherine asserts that after the Last Judgement consequent to the Saviour's crucifixion and resurrection - the human nature would be regenerated and the saved ones would benefit from a transfer of the spiritual abundance, acquired through divine grace, to the body. ${ }^{96}$ All the more, in the same fragment concerning Saint Agnes, there is a clear reference to Catherine's own experience of foodless

93 Dailey, Promised Bodies, especially 2, 8. Regarding the authoritative role of the Scripture for (female) mysticism see R. Rusconi, "La storia religiosa ‘al femminile e la vita religiosa delle donne," in Innesti: donne e genere nella storia sociale, ed. Giulia Calvi (Roma: Viella, 2004), 175-195, especially 184.

94 As a principle of mysticism denotes, the body is made available for the soul, in order to perform God's mission. Michel de Certeau, Fabula mistică [The Mystic Fable] (Iaşi: Polirom, 1996), 83.

95 "perché pure dell'erba non vive il corpo della creatura, parlando comunemente e in generale di chi non è perfetto..." Il Dialogo CXLIX, 159. Elsewhere, the Holy Sacraments are referred to as food for the soul, which is the true nourishment of life: "Tu vedi che ne l'anima, per la vita sua, Io l'ò dati i sacramenti della santa Chiesa, perché sono suo cibo: non il pane, che è cibo grosso e corporale e dato al corpo, ma perch'ella è incorporea vive della parola mia. Però disse la mia Verità nel santo Evangelio che di solo pane non viveva l'uomo, ma d'ogni parola che procede da me, cioè di seguitare con espirituale intenzione la dottrina di questa mia Parola incarnate". Ibidem, CXLII, 147-148.

96 "Sì che non è il corpo che dia beatitudine all'anima, ma l'anima darà beatitudine al corpo: darà dell'abbondanzia sua, rivestita ne l'ultimo dì del giudicio del vestimento della propria carne la quale lassò. Come l'anima è fatta immortale, fermata e stabilita in me, così il corpo in quella unione diventa immortale: perduta la gravezza è fatto sottile e leggiero. Unde sappi che 'l corpo glorificato passerebbe per lo mezzo del muro, né il fuoco né l'acqua non l'offenderebbe; non per virtù sua ma per la virtù dell'anima, la quale virtù è mia, data a lei per grazia, e per amore ineffabile col quale Io la creai alla imagine e similitudine mia." Ibidem, XLI, 34. 
survival. ${ }^{97}$ To conclude, the saint's thinking - as well as her disciples' subordinates to the logic of the immanence of God, who directly communicates with his creatures and actively intervenes in their lives. ${ }^{98}$ The hagiographic accounts on Catherine of Siena - particularly thoughtful about the supernatural dimension of her existence -, as well as the teachings of the saint - which primarily deal with the ideal of imitating Christ's humanity and his suffering - converge towards the same Christological framework. While the theme of Catherine's Christification may seem a cliché indebted to hagiographic conventions - certainly based on the prominent influence of theology and ultimately of religious belief -, this standpoint shall be amended in accordance with the saint's writings. The latter comprise an inner insight into what clearly appears to be an actual happening - specifically, her inability to eat in a natural way -, which complements and confirms the claims of her devotees regarding their personal experience of this token of divine grace.

\section{Conclusion}

The attitude regarding food evinced by Saint Catherine of Siena provides us with a glimpse into the core of sainthood, as it has been understood by late medieval Christianity; all the more concerning the ascetical and mystical path, the Christological reference is indispensable, so that the saints are believed to share and reflect the virtues of the Saviour. Through fasting, the Sienese virgin embraced penance as a means to acknowledge and fight against the sinful state, applying to imitatio crucis. Subsequently, after becoming mystically united with Christ and being granted a whole new, spiritualized, ontological status, the saint would be unable to eat and only survived on the Holy Communion. However, she endured tremendous pain in an effort to feed herself according to nature and found it a gift from God, in order to correct her vices and expiate the sins of her neighbour. Therefore,

97 Thus God can offer the righteous the following privilege: "davo e do una disposizione a quel corpo umano, in tanto che meglio starà con quella poca de l'erba, $\mathrm{O}$ alcuna volta senza cibo, che inanzi non faceva col pane e co' l'altre cose che si dànno e sono ordinate per la vita de l'uomo. E tu sai che egli è così, ché l'ài provato in te medesima." Ibidem, CXLIX, 159.

98 Against this background, the saint ultimately ascribes her fleshly burden to the divine will. Lettere CXXIV, 399. 
through suffering, Catherine partook the human nature of the Lord and was promised that, correspondingly, she would also benefit from His glory.

There is undoubtedly a cultural ethos and a historical background in which the Catherinian example integrates: it shapes the saint's experience, respectively her posthumous image, adjusting her fasting either ascetical or glorious - to a pre-established pattern. Nevertheless, Catherine's inability to consume earthly food was an authentic fact for both her disciples and the saint herself. Although the writings on, respectively by the saint focus on different aspects, the hagiographic portrait and Catherine's own interests converge towards the same ethical, anthropological, and cosmological paradigm, that ultimately consider fasting and its further implications in a theological setting. ${ }^{99}$ Thereby, the question related to Catherine's supernatural sustenance aside from providing the opportunity to partake of Christ's redemptive suffering - testifies to the genuine belief in the transformability of matter according to the spirit as a result of the saint's Christification, and eventually foreshadows the promised deification of the entire creation.

\section{References}

\section{Primary sources}

S. Bonaventura. Legenda maior S. Francisci Assisiensis et eiusdem Legenda minor. Florence, Quaracchi: Typographia Colegii S. Bonaventurae, 1941.

Caffarini, Tommaso Nacci. Vita di S. Caterina da Siena scritta da un divoto della medesima con il supplemento alla vulgata legenda di detta santa, ed. Ambrogio Ansano Tantucci. Siena: Stamperia di Luiggi e Benedetto Bindi, 1765.

S. Caterina de Siena. Il Dialogo, ed. Giuliana Cavallini. Siena: Cantagalli, 1995.

\footnotetext{
${ }_{99}$ This finding prompts us to rethink, at least in this particular case, the bias concerning the distance between female religiosity and its perception by their male entourage. In this respect, see Gendered Voices. Medieval Saints and their Interpreters, ed. Catherine M. Mooney (Philadelphia: University of Pennsylvania Press, 1999), particularly A. Hollywood's contribution, "Inside out: Beatrice of Nazareth and her Hagiographer," 78-98.
} 
S. Caterina da Siena, Le Oraz̧ioni, ed. Giuliana Cavallini. Rome: Edizioni Cateriniane, 1978.

Fonti Clariane, ed. Chiara Augusta Lainati. http:/ /www.assisisantachiara.it/wpcontent/uploads/downloads/2012/08/Fonti-Clariane.pdf (Last accessed: March 1, 2016).

Il Processo Castellano. Santa Caterina da Siena nelle testimonianze al Processo di canonizzazione di Veneria, ed. Tito S. Centi and Angelo Belloni. Florence: Edizioni Nerbini, 2009.

Il processo di Santa Chiara d'Assisi, ed. Nelo Vian. Milano: Editrice Vita e Pensiero, 1962.

Lettere di Caterina da Siena, ed. P. Misciatelli. Florence: Marzocco, 1939. Sainte Claire d'Assise. Sa Vie par Thomas de Celano. Ses Écrits, ed. Damien Vorreux. Paris: Éditions Franciscaines, 1953.

Raymond of Capua. The Life of Saint Catherine of Siena. Dublin: James Duffy and Co., s.a.

Thomas Aquinas, Summa Theologiae, trans. by Fathers of the English

Dominican Province, online ed. Kevin Knight, 2016.

http://www.newadvent.org/summa/5.htm (Last accessed:

December 4, 2017).

Vie de Saint François d'Assise, ed. Damien Vorreux. Paris: Éditions

Franciscaines, 1952.

\section{Secondary literature}

Bell, Rudolph M. Holy Anorexia. Chicago: The University of Chicago Press, 1985.

Brumberg, Joan Jacobs. Fasting Girls: The History of Anorexia Nervosa as a Modern Disease. Cambridge, London: Harvard University Press, 1988. Burr, Jacques. Sens chrétien de l'histoire. Initiation au Mystère du Salut. Paris: Éditions P. Téqui, 1973.

Bynum, Caroline Walker. Fragmentation and Redemption: Essays on Gender and the Human Body in Medieval Religion. New York: Zone Books, 1991. . Holy Feast and Holy Fast. The Religious Significance of Food to Medieval Women. Berkeley, Los Angeles: University of California Press, 1987.

. The Resurrection of the Body in Western Christianity, 200-1336.

New York: Columbia University Press, 1995. 
Casagrande, C, Vecchio, S. "Păcatul" [The Sin]. In Dicționar tematic al Evului Mediu occidental. Jacques Le Goff, Jean-Claude Schmitt, eds., 584-593. Iaşi: Polirom, 2002.

Cavallini, Giuliana. "La verità nell'ascesi cateriniana.” Roma: 1974. http:/ /www.centrostudicateriniani.it (Last accessed: October 12, 2017).

de Certeau, Michel. Fabula mistică [The Mystic Fable]. Iaşi: Polirom, 1996.

Cid, María del Mar Graña. "Mística feminina e semellanza das mulleres con Cristo A propósito de santa Catarina de Siena." Revista galega de pensamento cristián 16 (2009): 73-84.

Clément, Olivier. Riflessioni sull'uomo. Milan: Editoriale Jaca Book, 1991.

Covaciu, C. "Între memorie şi venerare. Imaginea sfintei Clara de Assisi in procesul de canonizare" [Between Memory and Veneration. The Image of Saint Clare of Assisi in the Canonization Process. Buletinul Cercurilor Stïnțifice Studențești Ştïnțifice Studentesți Arheologie - Istorie Muzeologie [Bulletin of Student's Scientific Circles Archeology History - Museology] 22 (2016): 83-115.

. "What Else Do We Have but a Body? Reflections on an Apparent Paradox." Studia Universitatis Babeş-Bolyai, Historia 60/1 (2015): 133-154.

Dailey, Patricia. Promised Bodies. Time, Language and Corporeality in Medieval Women's Mystical Texts. New York: Columbia University Press, 2013.

Dalarun, Jacques. Dumnezeu şi femeia [God and the Woman]. Bucharest: Artemis, 2009.

Delooz, P. "Pour une étude sociologique de la sainteté canonisée dans l'Eglise catholique." Archives de sociologie des religions 13 (1962): 17-43.

Dunn, Marilyn. The Emergence of Monasticism. From the Desert Fathers to the Early Middle Ages. Oxford: Blackwell Publishing, 2003.

Fudgé, T. Medieval Religion and its Anxieties. History and Mystery in the Other Middle Ages. New York: Palgrave Macmillan, 2016.

Gajano, S. Boesch. "Sfințenia" [Sainthood]. In Dicţionar tematic al Evului Mediu occidental [Thematic Dictionary of Western Middle Ages], ed. Jacques Le Goff, Jean-Claude Schmitt, 734-744. Iaşi: Polirom, 2002. Hanson, S. "Connections between Body and Soul: the Asceticism of Medieval Saints." The UCI Undergraduate Research Journal XII (2009): 23-34. 
Hinnenbusch, William A. Dominican Spirituality. Principles and Practice. Washington, D.C.: Our Lady of the Rosary Province, 1965. http://www.holyrosaryprovince.org/2011/media/essencial/domini can_spirituality.pdf (Last accessed: October 11, 2017).

Hollywood, A. "Inside out: Beatrice of Nazareth and her

Hagiographer." In Gendered Voices. Medieval Saints and their Interpreters, ed. Catherine M. Mooney, 78-98. Philadelphia: University of Pennsylvania Press, 1999.

Klaniczay, Gábor. "Illness, Self-inflicted Body Pain and Supernatural Stigmata: Three Ways of Identification with the Suffering Body of Christ." In Infirmity in Antiquity and the Middle Ages. Social and Cultural Approaches to Health, Weakness and Care, ed. Christian Krötzl, Katariina Mustakallio, Jenni Kuuliala, 119-136. Farnham: Ashgate, 2015.

Klapisch-Zuber, C. "Masculin/feminin” [Male/Female]. In Dicţionar tematic al Evului Mediu occidental [Thematic Dictionary of Western Middle Ages], ed. Jacques Le Goff, Jean-Claude Schmitt, 440-449. Iaşi: Polirom, 2002.

Lawrence, C. H. Medieval monasticism. Forms of Religious Life in Western Europe in the Middle Ages. New York: Longman, 1984.

Ledda, G. "Cibi del Paradiso." In Banchetti letterari, ed. G. M. Anselmi, G. Ruozzi, 118-125. Rome: Carocci, 2011.

Lester, R. "Embodied Voices: Women's Food Asceticism and Negotiation of Identity." Ethos 23/2 (1995): 187-222.

Louth, A. "The body in Western Catholic Christianity"]. In Religion and the Body, ed. Sarah Coakley, 111-130. Cambridge: Cambridge University Press, 1997.

Lemeneva, E. "The Borders and Borderlines of Sainthood: on the Stigmata of St. Catherine of Siena." Annual of Medieval Studies at Central European University Budapest 6 (2000): 193-202.

Masson, J. M. "The Psychology of the Ascetic." Journal of Asian Studies, 35/4 (1976): 611-625.

McGinn, B. "The Changing Shape of Late Medieval Mysticism." Church History 65/2 (1996): 197-219.

Ochsenbein, P. "Mistica della sofferenza nei conventi femminili domenicani del secolo XIV secondo l'esempio di Elsbeth di Oye." In Movimento religioso e mistica femminile nel Medioevo, ed. Peter Dinzelbacher, Dieter Bauer, 398-419. Rome: Edizioni Paoline, 1993. 
Pelikan, Jaroslav. Tradiția creștină. O istorie a dęvoltării doctrinei [The Christian Tradition. A History of the Development of Doctrine]. Iaşi: Polirom, 2006, vol. III, Evolutia teologiei medievale (600-1300) [The Evolution of Medieval Theology (600-1300)].

Reda, M., Sacco, G. "Anorexia and the Holiness of Saint Catherine of Siena." Journal of Criminal Justice and Popular Culture 8/1 (2001): 37-47. Romagnoli, A. Bartolomei. "Il corpo dell'estasi. Il lingaggio delle immagini dal medioevo al barocco." Donne nello specchio dell'Altissimo. Cuaderni di Arte, Cultura e Spiritualità (2014): 13-46.

. "Il francescanesimo femminile dalle origini al Concilio di Trento." In All'ombra della chiara luce, ed. Aleksander Horowski, 1318. Rome: Istituto storico dei Cappuccini, 2005. . "La disputa sulle stimmate." In Virgo digna coelo. Caterina e la sua eredità. Raccolta di studi in occasione del $550^{\circ}$ anniversario della canonizzazione di santa Caterina da Siena (1461-2011), ed. Alessandra Bartolomei Romagnoli, Luciano Cinelli, Pierantonio Piatti, 407-446. Vatican City: Libreria Editrice Vaticana, 2013. . "La mistica, il dolore, la croce." Cultura e fede 22 (2014): 100114.

Rusconi, R. "La storia religiosa 〈al femminiles e la vita religiosa delle donne." In Innesti: donne e genere nella storia sociale, ed. Giulia Calvi, 175-195. Rome: Viella, 2004.

Steinbock, Anthony J. Phenomenology and Mysticism: The Verticality of Religious Experience. Bloomington, Indianapolis: Indiana University Press, 2007.

von Thaden, R. "Glorify God in Your Body: The Redemptive Role of the Body in Early Christian Ascetic Literature." Cistercian Studies Quarterly 38.2 (2003): 191-209.

Tinsley, David F. The Scourge and the Cross: Ascetic Mentalities of the Later Middle Ages. Leuven: Peeters, 2010.

Vauchez, André. Sainthood in the Later Middle Ages. Cambridge: Cambridge University Press, 1997. . "The Saint." In The Medieval World, ed. Jacques Le Goff,

313-325. London: Collins \& Brown, 1991.

Ware, K. "My helper and my enemy: the body in Greek Christianity." In Religion and the Body, ed. S. Coakley, 90-110. Cambridge: Cambridge University Press, 1997.

Webb, H. "Catherine of Siena's Heart.” Speculum 80/3 (2005): 802-817. 
Electronic sources

https://epistolae.ccnmtl.columbia.edu/letter/569.html (Last accessed: October 11, 2017), letter 569. 